\title{
Undergraduate Research-Methods Training in Political Science: A Comparative Perspective
}

Jonathan Parker, Keele University

ABSTRACT Unlike other disciplines in the social sciences, there has been relatively little attention paid to the structure of the undergraduate political science curriculum. This article reports the results of a representative survey of 200 political science programs in the United States, examining requirements for quantitative methods, research methods, and research projects. The article then compares the results for the United States with a survey of all political science programs in Australia, Canada, Finland, the Netherlands, Norway, Sweden, and the United Kingdom. The results suggest (1) that the state of undergraduate methods instruction is much weaker in the United States than indicated in previous research, (2) this pattern is repeated in other countries that emphasize broad and flexible liberal arts degrees, and finally (3) this pattern of weak methods requirements is not found in more centralized, European higher education system that emphasize depth over breadth. These countries demonstrate a consistent commitment to undergraduate training in research methods that is followed up with requirements for students to practice hands-on research. The model of weak methods requirements in the discipline is not the norm internationally, but differs depending upon the type of higher education system.

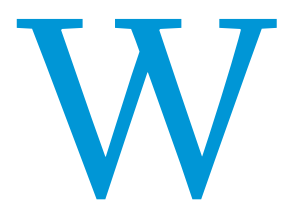

hat is the state of undergraduate researchmethods training in political science? The American Political Science Association's Task Force on Political Science in the 21st Century is currently examining the curriculum and pedagogical approaches of both undergraduate and graduate programs. Until now, little attention has been directed at the undergraduate curriculum (Ishiyama, Breuning, and Lopez 2006). The 1991 APSA report The Political Science Major in the Liberal Arts Curriculum, popularly dubbed the "Wahlke Report," was the last official report to examine the structure of undergraduate education and make specific proposals (Wahlke 1991). The report was part of the Association of American Colleges (AAC) (now the Association of American Colleges and Universities), which commissioned reports from 12 different subjects. The recommendations for political science resemble those for other subjects, which uni-

Jonathan Parker is a senior lecturer in political science at Keele University. His research interests are public policy, particularly education. His current research is in higher education policy, particularly examining the undergraduate curriculum in the social sciences and comparing different approaches to undergraduate education across countries. He is a National Teaching Fellow of the UK Higher Education Academy. formly criticize the unstructured curricula found throughout colleges and universities (Association of American Colleges 1991). The report calls for an integrated and sequential set of courses rather than a randomly sequenced jumble of choices. In particular, the report recommends a common introductory course, a methods course taken early, and a senior seminar or capstone course at the end. However, there is little evidence that the Wahlke Report had much impact on the discipline. Kim Quaile Hill's (2002) lamentation over the state of science education observes that few departments require any systematic training in methodology. A survey of universities in 10 midwestern states finds only $18 \%$ had the three structural elements recommended in the report (Ishiyama 2005). Political science in the United States has generally neglected methods education in favor of a broader exposure to the different subfields (Thies and Hogan 2005). This lack of attention and consensus over a common standard is not shared by other disciplines in the social sciences, such as psychology and sociology, whose national associations have commissioned reports on the undergraduate degree more frequently and made more detailed recommendations on the content and structure of the undergraduate degree (Halonen et al. 2007; Kain 2007; McKinney et al. 2004). 
Recent studies of undergraduate methods requirements suggest that this area of teaching is not an agreed priority for political science degrees. Thies and Hogan (2005) surveyed political science departments by e-mail and their results from over 300 programs show that, on average, $64 \%$ required a methods course of some type for a political science or social science degree. However, within this overall average, only $46 \%$ of undergraduate programs at more elite, Ph.D.-granting institutions require methods for a political science degree versus $73 \%$ of universities offering only undergraduate degrees. This split confounded conventional wisdom since the departments with the most resources, largest staff sizes, and strongest research orientation were the least likely to require undergraduate methods training. Nonetheless, finding that almost $64 \%$ of undergraduate political science degrees required research methods was a cause for optimism over its status in the discipline. However, this high proportion has not been replicated in other studies.

Doyle and Mezzell (2007) examine the curricula in 10o Ph.D. programs in the U.S. and find that only $31 \%$ of degrees required methods training. Dell and Nakazato (2007) examine 224 university programs drawn from the list of national and liberal arts universities listed in U.S. News and World Report's college rankings and find that only $36 \%$ of all programs required research methods. Further, they find little difference between national (research) universities (33.9\%) and liberal arts universities (37.3\%). U.S. News's categories of "national" and "liberal arts" differ from those used by Thies and Hogan, so the results of the two studies are not directly comparable. Nonetheless, the more recent studies suggest a much smaller commitment to methods training across the entire discipline. Dell and Nakazato also report a sizeable proportion $(12 \%)$ of universities requiring an undergraduate dissertation, project, or thesis, though this figure is attributable to half the survey consisting of liberal arts colleges, which traditionally support this type of assessment.

While there are now multiple sources of data on the prevalence of methods requirements in undergraduate political science degrees in the United States, none of these studies emerges as a definitive depiction of the discipline or examines a nationally representative sample of programs. All three studies overrepresent research universities, which tend to have weaker methods requirements. Further, there has been no attempt to examine political science programs in other countries. There are some general summaries and descriptive accounts of methods training in countries such as the United Kingdom (Mills et al. 2006; HEFCE 2005), Canada (SSHRC 2005), and Sweden (Högskoleverket 2006), but there are no detailed surveys of practice across the discipline.

This study surveys methods teaching and research in undergraduate political science degrees in Australia, Canada, Finland, the Netherlands, Norway, Sweden, the United Kingdom, and the United States. Much of the data come from a benchmarking report on the teaching of methods in undergraduate programs for the Economic and Social Research Council (ESRC) of the UK. (Parker et al. 2008). This report selected countries because of their success in producing social science doctorates and comparability to the United Kingdom. The sample is weighted towards northern Europe and Anglophone countries and does not purport to represent the state of the discipline across the world, but it provides a comparison of political science degrees across a wide range of countries.
Table 1

Representativeness of the Sample Compared to the Universe by Degree Program in the United States

\begin{tabular}{lcc} 
HIGHEST DEGREE AWARDED & $\begin{array}{c}\text { PERCENT OF TOTAL } \\
\text { INSTITUTIONS LISTED } \\
\text { IN THE APSA DIRECTORY }\end{array}$ & $\begin{array}{c}\text { PERCENTAGE OF } \\
\text { INSTITUTIONS } \\
\text { IN THE SAMPLE }\end{array}$ \\
\hline BA Combined Programs & 21 & 19 \\
\hline BA Social Science & 17 & 19 \\
\hline BA Political Science & 40 & 41 \\
\hline MA Political Science & 12 & 14 \\
\hline Ph.D. Political Science & 10 & 8 \\
\hline Overall & 100 & 100 \\
\hline$N=$ & 1,268 & 195 \\
\hline
\end{tabular}

\section{DATA AND METHODS}

Political science degree requirements are surveyed from a sample of universities in each country to identify compulsory courses in quantitative methods, general research methods, and student research projects, theses, or dissertations. Only major concentrations or degrees in political science, politics, or government were included. Optional or elective courses were excluded because there is no guarantee that a student would take that particular class.

The sample for each country, aside from the U.S., included all universities. Political science degrees or concentrations are offered in 30 universities in Australia, 66 in Canada, 7 in Finland, 4 in the Netherlands, 6 in Norway, 14 in Sweden, and 172 in the United Kingdom. The data from the United States consists of a random sample of 200 political science programs identified in the APSA Directory of Political Science Faculty and Programs in 2007. Of these 200 programs, 195 offered majors or degrees in political science (see table 1).

Mandatory course requirements for undergraduate degrees or majors in each subject are from university catalogs and Web sites. There are limitations to the accuracy of course information in university catalogs, particularly concerning which classes are actually running and the extent to which their content reflects their description. However, catalogs and Web sites are important tools for universities to advertise their majors, and provide an efficient and relatively accurate way of obtaining information about the structure and requirements of a degree, which are much less likely to change than particular course offerings (Ishiyama 2005). The number of courses in quantitative methods, general research methods, and student research projects were recorded, along with their relative credit weightings, using the course titles and descriptions from the Web sites, course catalogs, and online syllabi. The following definitions were used to categorize courses as quantitative methods, research methods, and theses, dissertations, or research projects.

\section{Quantitative Methods}

Williams, Collett, and Rice (2004) in their survey of sociology in the UK, define quantitative methods as experimental method, survey methods, quantitative data analysis, and statistics. Any 
required couses in these topics, based upon their titles and descriptions, were classified as quantitative methods. General requirements to do a mathematics course as part of a liberal arts curriculum or even recommendations to take a particular statistics course were not counted because they do not ensure that students take quantitative methods as opposed to some other topic.

\section{Research Methods}

This classification covers a broad range of topics covering any research methods not defined as quantitative. These topics include epistemology, methods, and research design. The courses define what research is, categorize the different types and the different ways it can be carried out, and explain different methodologies used to conduct it. Typically, the courses included are just named Research Methods, Scope and Methods, or Research Design. One common approach is to split a course and have half quantitative methods and half scope and methods. In cases where half the course is clearly dedicated to teaching quantitative methods, then it was coded as .5 research methods and .5 quantitative-methods.

\section{Theses, Dissertations, and Research Projects}

Many academics would traditionally call this course a senior honors thesis, but the course descriptions and types of research involved have expanded far beyond the scope of that single label. This classification consists of courses where students design and engage in their own research. It can be called a thesis, dissertation, research project, capstone course, or senior seminar. This designation was not applied to every course fulfilling senior writing requirements or senior capstone seminars. These types of classes may have a strong written component but the act of writing a paper is not the same as engaging in an independent research project. This particular category should apply only to courses dedicated to the practice of research and the research process, including designing and conducting research or participating in a research project and writing up the results.

\section{Credit Weighting}

Comparing courses across universities in the United States is a daunting exercise due to the multitude of credit systems and student workloads operating in different institutions. Extending the comparison across countries greatly multiplies this problem. One possible solution is to calculate the number of credits needed for an undergraduate degree and classify courses as a set percentage of that degree. For example, a typical undergraduate degree in the United States would consist of 120 credits, so a single 3 -credit course would constitute $2.5 \%$. However, countries differ over how many years it takes to complete an undergraduate degree. Under the Bologna Accords, European countries generally require three years instead of four, and some countries, such as Canada and
Australia, require a fourth year to attain an honor's degree. Classifying courses as a percentage of a degree would inflate the weightings in shorter degree programs for the same amount of work and instruction, so it does not work well for comparing across countries.

This study uses course data to construct simple distribution tables, so such a precise detail is unnecessary. It adopts a quick rule of thumb that courses should be standardized based on their percentage of a full year's coursework. Most universities operate on an 8- to 10-course workload per year so there is consistency both within and across countries. Credit weightings are collected in order to classify courses as a half, single, or double according to their proportion of a year's course load. For example, in the United States if students take 30 credits per year, then 1 or 2 credits were labeled a half-course while 3 or 4 credits were categorized as one course. The credit systems did not vary much within most countries, so this system worked well as a simple way to code courses by their credits.

\section{RESULTS}

Table 2 reports the results for universities in the United States. The figures show a strikingly low proportion (28\%) of departments that require any methods training, which is much lower than Thies and Hogan's overall figure of $64 \%$. The discrepancy may be attributable to selection bias in their survey, which reports data from departments that chose to respond to an e-mail survey about their methods teaching. One would expect that departments more committed or more able to provide this training were also more likely to provide an e-mail address to the APSA database and to reply to the survey.

All previous studies have found that research universities are less likely to require such training, and this study confirms that relationship, with only $25 \%$ of research universities requiring any methods training. The figures are, again, much lower than Thies and Hogan's (47\%) and slightly lower than Dell and Nakazato's (34\%) and Doyle and Mezzell's (31\%). The latter two studies are based upon surveys of curriculum documents at research universities. Doyle and Mezzell use a similar source for their sample, surveying 100 out of $122 \mathrm{Ph}$.D. programs from the same APSA database. Their results are also the most similar to this study's results, supporting the suggestion that the differences in results are due to sample selection. 


\begin{tabular}{|c|c|c|c|c|}
\hline COUNTRY & $\begin{array}{l}\text { PERCENTAGE OF } \\
\text { UNIVERSITIES } \\
\text { REQUIRING } \\
\text { QUANTITATIVE } \\
\text { METHODS }\end{array}$ & $\begin{array}{l}\text { PERCENTAGE OF } \\
\text { UNIVERSITIES } \\
\text { REQUIRING } \\
\text { RESEARCH } \\
\text { METHODS }\end{array}$ & $\begin{array}{l}\text { PERCENTAGE OF } \\
\text { UNIVERSITIES } \\
\text { REQUIRING } \\
\text { RESEARCH } \\
\text { PROJECT/THESIS }\end{array}$ & $\begin{array}{l}\text { TOTAL NUMBER } \\
\text { OF UNIVERSITIES }\end{array}$ \\
\hline Australia & 0 & 10 & 0 & 30 \\
\hline Canada & 20 & 20 & 2 & 66 \\
\hline Finland & 14 & 71 & 57 & 7 \\
\hline Netherlands & 75 & 100 & 100 & 8 \\
\hline Norway & 50 & 67 & 33 & 6 \\
\hline Sweden & 7 & 79 & 100 & 14 \\
\hline United Kingdom & 10 & 44 & 71 & 172 \\
\hline United States & 20 & 24 & 17 & 195 \\
\hline
\end{tabular}

The consistent provision of research methods in the curriculum of over half the survey countries raises the question of what purpose this training serves. Pedagogical literature on methods teaching is filled with warnings about teaching students in a single, isolated course with no connection to the rest of the curriculum. The literature on methods teaching also urges teachers to get students doing research or working with data as quickly as possible in order to reinforce academic lessons from the classroom. The last category, requirements for research projects or a thesis, shows that countries most likely to insist upon research-methods training are also most likely to get their students to use this training. Finland, the Netherlands, Sweden, and the United Kingdom require undergraduate research for political science degrees in a majority of universities, with the Netherlands and Sweden requiring it in all programs. Most of these requirements involve more than one course, so even

The results for methods requirements in degree programs at universities that do not offer graduate degrees are also much lower than those reported by Thies and Hogan. Their survey finds that $77 \%$ of combined programs, $74 \%$ of social science programs, and $61 \%$ of separate political science programs require methods. Again, their use of e-mail surveys introduces a degree of bias in the responses. The respective figures of $16 \%, 50 \%$, and $31 \%$ from this study suggest that the actual state of methods training throughout the discipline is much lower than previously reported.

The figures for senior-thesis or research-project requirements were very similar to the findings of Dell and Nakazato for research universities (6\%) and liberal arts universities (19\%). Again, a stark difference between universities with and without graduate programs is apparent. A senior thesis is required in $21 \%$ of universities without graduate programs in political science but they are all but nonexistent in programs with an MA or Ph.D.

Previous studies overestimate the extent of undergraduate methods training and research. While these requirements appear particularly sparse in American political science programs, particularly in comparison to other disciplines, such as sociology or psychology, their relative frequency has not been compared with political science programs in other countries. Table 3 compares results across eight countries. While few countries consistently require quantitative methods, the European countries consistently require both research methods and research projects for undergraduate degrees. Only the Netherlands and Norway require quantitative training in a majority of programs, and no other country has this requirement in more than $20 \%$ of universities. However, Norway usually requires only a half-course in its programs, so only the Netherlands demands at least one full course in most programs.

Half the countries in the study require at least one course of research methods in a majority of political science programs. Finland, the Netherlands, Norway, and Sweden require their students to take research methods in over two-thirds of departments. The United States, Canada, and Australia stand out for their consistent lack of required research-methods training in most programs while the United Kingdom falls in between these two groups with a requirement in $44 \%$ of programs. these high figures underestimate its importance in the overall degree.

\section{FINDINGS}

These results confirm the low level of requirements for research methods found in previous surveys of American undergraduate programs in political science. The survey finds that only $20 \%$ of programs require quantitative methods, $24 \%$ of programs require research methods, and $17 \%$ require a thesis or research project. The comparative figures reinforce the image of a relatively weak state of methods teaching and research at undergraduate level in the U.S., Canada, and Australia, which generally support broadbased liberal arts approaches to undergraduate degrees. This lack of training is not found among political science departments across the European countries, which tend to have more centralized, government-regulated systems with stronger concentrations in single subjects.

The European countries all generally offer three-year undergraduate degrees, with the exception of Scotland's four-year degree, that emphasize depth over breadth. These countries also more frequently require research-methods training to a much greater extent. Undergraduate degrees in these countries do not promote the liberal arts ideal of experience in many different subjects to the same extent. More the opposite, students are expected to select one or two subjects and concentrate upon them for most of their degrees. For example, in the Netherlands political science degrees closely resemble the curricula of the natural sciences with their high levels of prescribed training with little room for electives.

While more highly prescriptive than traditional liberal arts degrees, these programs carefully sequence their students' coursework in a coherent package. Most importantly, those universities with the most rigorous methods training do not separate research methods from practice. The purpose of methods is seen as enabling students to carry out such academic work, which is seen as incorporating very active and independent learning of the highest levels found in undergraduate teaching. Finally, this integrated approach to undergraduate research training and practice is required of all students and is assumed to constitute a fundamental part of a social science degree that is neither optional nor 
restricted to more academically able students. This structure closely follows the logic of an integrated curriculum found in the Wahlke Report (1991) and in some liberal arts colleges in the U.S. (Ishiyama and Hartlaub 2003). The distinct approaches of the broad and flexible liberal arts degree versus the more focused and specialized European degree highlight clear differences between education aims, and they also demonstrate that the weak state of undergraduate methods training in the United States is by no means the norm for political science.

\section{REFERENCES}

American Association of Colleges. 1991. "Political Science." In Reports from the Fields: Project on Liberal Learning, Study-in-Depth, and the Arts and Sciences Major. Vol. 2. Washington, D.C.: AAC.

Dell, Kyle D., and Hiroshi Nakazato. 2007. “'Neither Fish Nor Fowl': When Are Research Methods Taught in Undergraduate Political Science Programs?" Presented at the American Political Science Association Learning and Teaching Conference, Charlotte, NC.

Doyle, Jeffrey Todd, and Ann Mezzell. 2007. "The Undergraduate Methods Experience: Short-Changing the Future of Political Science." Presented at the American Political Science Association Learning and Teaching Conference, Charlotte, NC.

Halonen, Jane S., Drew C. Appleby, Charles L. Brewer, William Buskist, Angela R. Gillem, Diane Halpern, G. William Hill IV, Margaret A. Lloyd, Jerry L. Rudmann, and Valjean M. Whitlow. 2007. APA Guidelines for the Undergraduate Psychology Major. Washington, D.C.: American Psychological Association.

HEFCE (Higher Education Funding Council for England). 2005. Strategically Important and Vulnerable Subjects: Final Report of the Advisory Group. Bristol: Higher Education Funding Council for England.

Hill, Kim Quaile. 2002. "The Lamentable State of Science Education in Political Science." PS: Political Science and Politics 35 (March): 113-16.

Högskoleverket. 2006. Utvärdering av utbildning i statsvetenskap, freds- och utvecklingsstudier och områdesstudier vid svenska universitet och högskolor [Evaluation of training in political science, peace and development studies and area studies at Swedish universities and colleges]. Stockholm: Högskoleverket.

Ishiyama, John. 2005. "Examining the Impact of the Wahlke Report: Surveying the Structure of the Political Science Curriculum at Liberal Arts and Sciences Colleges and Universities in the Midwest." PS: Political Science and Politics 38 (January): 71-75.

Ishiyama, John, Marijke Breuning, and Linda Lopez. 2006. "A Century of Continuity and (Little) Change in the Undergraduate Political Science Curriculum." American Political Science Review 100 (4): 659-65.

Ishiyama, John, and Stephen Hartlaub. 2003. "Sequential or Flexible? The Impact of Differently Structured Political Science Majors on the Development of Student Reasoning." PS: Political Science and Politics 36 (January): 83-86.

Kain, Edward L. 2007. "The Sociology Major at Institutions of Higher Education in the United States." Teaching Sociology 35 (January): 31-47.

McKinney, Kathleen, Carla B. Howery, Kerry J. Strand, Edward L. Kain, and Cath erine White Berheide. 2004. Liberal Learning and the Sociology Major Updated: Meeting the Challenge of Teaching Sociology in the Twenty-First Century. Report of the ASA Task Force on the Undergraduate Major. Washington, D.C.: American Sociological Association.

Mills, David, Anne Jepson, Tony Coxon, Mark Easterby-Smith, Phil Hawkins, and Jonathan Spencer. 2006. Demographic Review of the UK Social Sciences. Swindon: Economic and Social Research Council.

Parker, Jonathan, Sue Scott, Andrew Dobson, and Matthew Wyman. 2008. International Benchmarking Review of Best Practice in the Provision of Undergraduate Teaching in Quantitative Methods in the Social Sciences. Milton Keynes: Economic and Social Research Council.

SSHRC (Social Sciences and Humanities Research Council of Canada). 2005. From Granting Council to Knowledge Council: Renewing the Social Sciences and Humanities in Canada. Ottawa: Social Sciences and Humanities Research Council of Canada.

Thies, Cameron G., and Robert E. Hogan. 2005. "The State of Undergraduate Research Methods Training in Political Science.” PS: Political Science and Politics $3^{8}$ (April): 93-97.

Wahlke, John C. 1991. "Liberal Learning and the Political Science Major: A Report to the Profession." PS: Political Science and Politics 24 (March): 48-6o.

Williams, M., T. Collett, and R. Rice. 2004. Baseline Study of Quantitative Methods in British Sociology. Plymouth: C-SAP and British Sociological Association. 